\title{
Factors associated with job satisfaction among graduate nursing faculties in Nepal
}

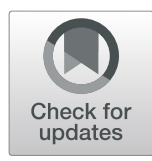

Abja Sapkota ${ }^{* *}$ (D) Usha K. Poudel ${ }^{2}$, Jyotsana Pokharel ${ }^{3}$, Pratima Ghimire ${ }^{3}$, Arun Sedhain ${ }^{4}$, Gandhi R. Bhattarai ${ }^{5}$, Binu Thapa ${ }^{6}$ and Tulza K.C

\begin{abstract}
Background: Job satisfaction among nursing faculty is critical to improving quality of nursing education, producing future nurses who will contribute directly to the health of patients at a local and national level. This study explores factors associated with job satisfaction among graduate nursing faculties in different universities of Nepal.

Methods: A cross-sectional study was conducted among nursing faculty with at least one year of teaching in their respective institutions. A 36-items job satisfaction questionnaire with 6-point Likert type responses was administered online. The questionnaire was pre-tested with 30 faculties pooled from multiple institutions. Link to the final survey was sent via e-mail to 327 nursing faculties working in 39 nursing colleges. Respondents were contacted by phone as a follow up to the email to politely remind them about the survey. Data analysis was carried out with SAS University Edition software. Chi-Square test and t-test were used for simple descriptive analysis. A multivariate binary logistic regression model was used to identify the significant factors associated with nursing faculties' job satisfaction. Adjusted odds ratio was calculated and significance was considered at $p \leq 0.05$ with $95 \%$ confidence interval.
\end{abstract}

Results: The response rate was $54.4 \%$. After retrospective cleaning of data, usable response rate was $52.3 \%$ ( $n=171)$. The average age of the nursing faculties was $36.8 \pm 7.0$ years. Based on the overall job satisfaction score, $36.8 \%$ nursing faculties were satisfied with their current job. The coefficient for Cronbach's alpha was 0.895 suggesting very good reliability of the overall measure. The significant factors associated with job satisfaction were the involvement of the faculties in decision making process related to the department $(O R=4.83)$ and adequate access to reference materials $(\mathrm{OR}=2.90)$.

Conclusions: This study suggests that nursing faculties have positive attitude towards their job but are dissatisfied with the benefits offered to them and the operating condition of their institutions. Expanding the teaching learning resources, such as reference books, subscription to journals, and continuing education opportunities for nursing faculties through participation in professional meetings would be helpful in improving the quality of nursing education in Nepal.

Keywords: Nursing faculty, Job satisfaction, Organizational characteristics

\section{Background}

Job satisfaction is an important component of improving job performance and maintaining the overall quality of work in any organization. Job satisfaction has been defined as the fulfilment of an employee's expectations for the work he or she performs [1]. It has also been described as a person's attitude with a correlation between expectations

\footnotetext{
* Correspondence: abjasapkota@nmcth.edu

${ }^{1}$ Department of Nursing, Nepal Medical College, Gokarneshwor- 44602,

Attarkhel, Jorpati Kathmandu, Nepal

Full list of author information is available at the end of the article
}

and outcomes at work [2]. It is well established that persons who are satisfied with their job tend to be more creative and innovative for better organizational performance [3]. Therefore, the result of job satisfaction will have an impact not only at the individual level but also in the institutional, societal, and national level. Multiple factors affect a person's job satisfaction, including pay, benefits and promotions, working condition, leadership and social relationship, diversities of tasks involved, and opportunities and challenges $[4,5]$.

(c) The Author(s). 2019 Open Access This article is distributed under the terms of the Creative Commons Attribution 4.0 International License (http://creativecommons.org/licenses/by/4.0/), which permits unrestricted use, distribution, and 
Nursing teachers are expected to perform multiple tasks that range from teaching nursing students, undertaking research activities, fulfilling an administrative role, facilitating support of staff in practice and providing patient care [6]. In nursing education, it is quite important to maintain and evaluate the satisfaction of teaching faculties because they are related to the production of nursing personnel who provide firsthand health service to the patients. The production of quality nurses with better values depends, to some extent, on the quality of a teacher [7]. When nursing faculties are satisfied with their job, they are more passionate about their work, delivering a higher quality education. Higher job satisfaction would result in lower faculty attrition, increased reputation of the institution, and higher recruitment of most qualified students.

Job satisfaction is a prime global concern and an important facet of any job, yet it has been rarely discussed and explored, especially in developing countries like Nepal. Although limited studies have explored few components of job satisfaction $[8,9]$, there is paucity of information on the overall job satisfaction of nursing faculties at the national level. It is imperative to understand their needs and expectations and address them sooner than later. This study aims to explore the level of job satisfaction and factors associated with it among the nursing faculties working in seven different Universities and Health Institutes in Nepal.

\section{Methods}

\section{Study population}

A cross-sectional study was conducted to explore the level of job satisfaction and factors associated with it among graduate nursing faculties in Nepal. At the time of the study initiation, 54 nursing colleges affiliated to seven universities offered baccalaureate or masters' level nursing degrees. All the faculty members who held at least a master's degree in nursing with current teaching responsibility at bachelors' level or higher for more than one year at the same institution were considered the population for the study. A census sampling technique was applied for the study. The name of the college was identified through a web search. Among the 54 colleges, four colleges could not be reached due to scheduling conflict, seven did not consent to participate in the study, and four colleges did not have faculties with a master's degree. The number of nursing faculties with at least a masters' degree from the remaining 39 colleges was 357 .

\section{Ethical clearance}

As the participants were from different institutions, ethical clearance was obtained from the institutional review committees of both Nepal Medical College (NMC), and Nepal Health Research Council (NHRC) before the initiation of the study. Upon approval from IRB, the campus chief from each nursing college was sent a formal letter to receive their institutional approval to conduct the study with their faculties. The respondents were asked to read the instructions and given an opportunity to decide whether would accept or decline the survey.

\section{Instrument}

The instrument was divided into three sections - the first and second sections included sociodemographic and organization related information. These sections were constructed by the researchers through literature search [10] and discussion with the experts. Third section consisted of a 36-item 'job satisfaction survey' developed by Spector [11] and used with his permission. Each question included 6-point Likert scale responses (1: disagree very much, 2: disagree moderately, 3: disagree slightly, 4: agree slightly, 5: agree moderately, and 6: agree very much). These questions covered nine different domains and included four questions in each domain. The total score ranged from 108 to 216 and domain scores ranged from 4 to 24 .

The questionnaire was posted online with the help of an expert in information technology. A link to the instrument was emailed to 30 randomly selected faculties as a pretest. They were followed up via email on a weekly basis for one month. A valid response was received from $56.6 \%$ of the faculties during pretesting. Data from these faculties were excluded from the main study.

\section{Data collection}

The final survey was sent to 327 faculties via a link to the online questionnaire (after excluding 30 pre-test sample). At least one facilitator was identified from each college, who would coordinate the timely delivery of responses from nursing faculties. These facilitators explained the research to participants and collected the mailing addresses of the nursing faculties, which were then sent to researchers. The researchers prepared a list of the faculties and then sent the questionnaire by mail. The researchers remained in frequent contact with the facilitators throughout the data collection period. The facilitators were provided with a remuneration of Nepalese rupees 500 (equivalent to USD 5) for coordinating the research at local level.

Responses were received from 178 (54.4\%) of the population. A retrospective cleaning was done to remove those with less than one year of service, those submitted a 'declined' response, or those currently not teaching at a graduate (bachelor and above) program. After this cleaning, 171 usable responses (52.3\%) were included in the final analysis (Fig. 1). 


\section{Data analysis}

The data analysis for this paper was done using SAS/ STAT software, Version 14. Copyright@ 2017 SAS Institute Inc. SAS and all other SAS Institute Inc. product or service names are registered trademark or trademarks of SAS Institute Inc., Cary, NC, USA. Simple descriptive analysis was done for data exploration. Chi-square test of dependence (for categorical variables) and t-tests (for continuous variables) were performed to check the relationship between job satisfaction and individual variables. Multivariate binary logistic regression model was used to identify factors associated with nursing faculties' job satisfaction. Adjusted odds ratio was calculated and significance was considered at $p \leq 0.05$ at CI $95 \%$.

Due to the design constrain during the delivery of online questions, a few demographics and institutionalrelated questions had some missing values. The missing rate was never higher than $7.5 \%$. Simple imputation was done by replacing the missing values by the mean (continuous variables such as age) or largest class (such as involvement in departmental decision making). There were no missing values in the response for job satisfaction questions.

\section{Results}

\section{Research participants' profile}

Out of 327 nursing faculties who were sent the questionnaire, 171 (52.3\%) were included in the final analysis.
The average age was $36.8 \pm 7.0$ years (range 26 to 57 years). Only $2.9 \%$ were male faculties. Most of the faculty had Master of Nursing (MN) degree (55.6\%), followed by Master of Science in Nursing (MSN, 40.9\%) and Doctorate in Nursing (PhD, 3.5\%).

Among the total respondents $(n=171), 60.8 \%$ were from private colleges and 39.2 were from public colleges. Overall, 58.5\% faculties were permanent (tenured), however there were disparities in tenure status among private colleges (45.2\%) and public colleges (79.1\%). Exactly two thirds of the faculties $(66.7 \%)$ worked as a Lecturer or lower position, followed by $18.7 \%$ as Associate Professor or higher level, and $14.6 \%$ as Assistant Professor. $38.0 \%$ of faculty had specialization in adult health (adult health nursing, medical-surgical nursing, critical care nursing and general nursing), followed by women's health (maternal health and women's health; 26.9\%), and child health (pediatrics and children's health; 17.5\%). Only 10.5 and $7.0 \%$ were specialized in psychiatric and mental health and community health, respectively.

\section{Job satisfaction score}

Slightly over one third (36.8\%) of the graduate nursing faculties were satisfied with their job. Dissatisfaction about their current job was observed only in $14.6 \%$ faculties, and a majority (48.5\%) had ambivalent feeling towards their job. Among the nine job satisfaction domains, highest job satisfaction was observed in

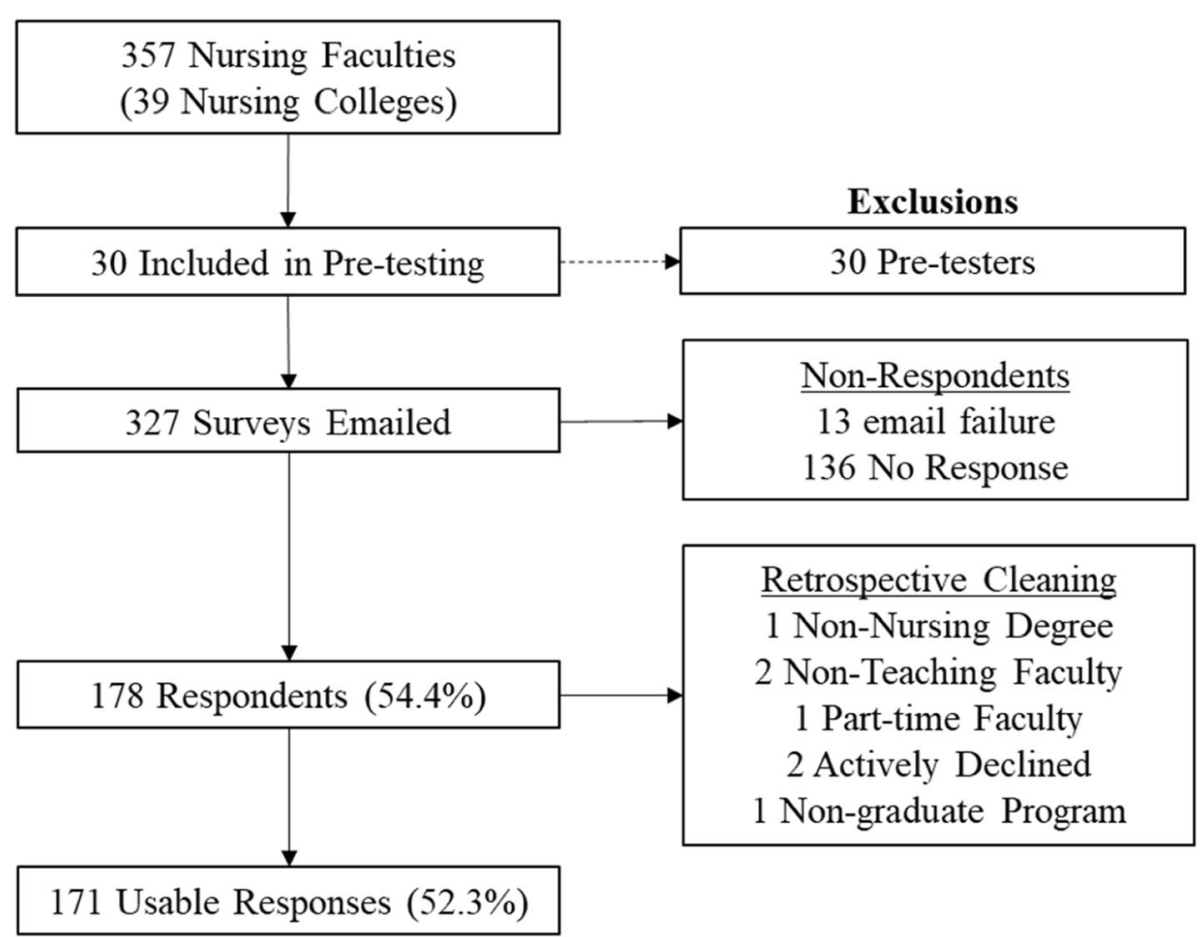

Fig. 1 Recruitment process of nursing faculties 
coworkers (81.3\%), followed by the nature of job (71.3\%), communication (70.8\%), and supervision (63.2\%). Most dissatisfaction was towards lack of promotion (56.1\%), contingency rewards (44.4\%), operating condition (44.4\%), pay (40.9\%), and fringe benefits $(35.1 \%)$. Only two domains, pay and supervision, have acceptable reliability score (Cronbach's alpha $>=0.70$ ). Hence, individual domain scores are not analyzed further, and the satisfaction categories are presented for informational purpose. (Table 1).

The primary objective of this study was to explore factors associated with overall job satisfaction among the graduate nursing faculty. Since majority of the respondents were ambivalent with few respondents expressively dissatisfied, we grouped these two categories as not satisfied as opposed to the respondents who were satisfied. This would allow us to run a multiple logistic regression model with a binary dependent variable (satisfied vs not satisfied).

\section{Sociodemographic characteristics of graduate nursing faculties by job satisfaction}

The details of sociodemographic and organizational characteristics of the faculties are shown in Table 2.

\section{Organizations related characteristics of nursing faculties by job satisfaction}

Majority of the nursing faculties (60.8\%) were from private organizations and $39.2 \%$ from the public institutions. Public institutions usually offer provident fund, grade, and promotional opportunities for their employees. In recent years, private institutions are also catching up in providing these benefits to both their tenured and non-tenured employees. For example, 76.6\% faculties responded positively about grade opportunity and $63.7 \%$ reported having provident fund benefits even though the overall employment in public colleges was $39.2 \%$ and tenure (permanent) rate was only $58.5 \%$.

A grade in Nepalese context is a periodic increment in the basic salary of employees after they have completed certain years of service. In other word, it can be defined as steps within the same grade level in the USA. On the other hand, a provident fund is a pension fund scheme for employees of both the public and private sectors in Nepal. This fund is managed by a government institution which invests the money to generate profit for the depositors. Under this scheme, eligible employees contribute $10 \%$ of their basic salary and employer matches the fund equally. This scheme operates similar to a 401(K) savings plan in the USA.

Healthcare benefits were reported by $74.3 \%$ of the respondents. Healthcare benefits in Nepalese context is an employer-provided welfare scheme that provides limited medical care within their network for an employee and their dependents. Immediate family members including spouse and children plus parents of both spouses are usually covered by this benefit.

A majority of respondents reported the availability and easy access to textbooks (74.9\%), reference books $(66.1 \%)$, nursing and medical journals (57.3\%) and internet facilities (83.6\%). (Table 3).

\section{Characteristics associated with job satisfaction}

The descriptive results showed that some of the variables have a stronger association with job satisfaction than others. In order to evaluate the effect of each of these factors while simultaneously controlling for other factors, a multiple logistic regression model was used. All variables with an effect size greater than 0.15 (see the correlation coefficient or Cramer's V statistics in

Table 1 Job Satisfaction of graduate nursing faculties

\begin{tabular}{|c|c|c|c|c|c|c|c|c|}
\hline \multirow{2}{*}{$\begin{array}{l}\text { Job Satisfaction } \\
\text { Domains }\end{array}$} & \multirow{2}{*}{$\begin{array}{l}\text { Score }(n=171) \\
\mu \pm \sigma\end{array}$} & \multicolumn{2}{|c|}{ Satisfied $^{1}$} & \multicolumn{2}{|c|}{ Ambivalent } & \multicolumn{2}{|c|}{ Dissatisfied } & \multirow[t]{2}{*}{ Reliability $^{2}$} \\
\hline & & Count & $\%$ & Count & $\%$ & Count & $\%$ & \\
\hline Pay & $13.8 \pm 4.9$ & 59 & $34.5 \%$ & 42 & $24.6 \%$ & 70 & $40.9 \%$ & 0.771 \\
\hline Promotion & $12.0 \pm 4.1$ & 42 & $24.6 \%$ & 33 & $19.3 \%$ & 96 & $56.1 \%$ & 0.446 \\
\hline Supervision & $16.7 \pm 4.5$ & 108 & $63.2 \%$ & 39 & $22.8 \%$ & 24 & $14.0 \%$ & 0.795 \\
\hline Fringe Benefits & $14.1 \pm 4.3$ & 62 & $36.3 \%$ & 49 & $28.7 \%$ & 60 & $35.1 \%$ & 0.527 \\
\hline Contingency Rewards & $13.1 \pm 4.1$ & 50 & $29.2 \%$ & 45 & $26.3 \%$ & 76 & $44.4 \%$ & 0.569 \\
\hline Operating Conditions & $12.9 \pm 3.2$ & 30 & $17.5 \%$ & 65 & $38.0 \%$ & 76 & $44.4 \%$ & 0.098 \\
\hline Coworkers & $18.3 \pm 3.4$ & 139 & $81.3 \%$ & 25 & $14.6 \%$ & 7 & $4.1 \%$ & 0.675 \\
\hline Nature of work & $17.1 \pm 3.4$ & 122 & $71.3 \%$ & 30 & $17.5 \%$ & 19 & $11.1 \%$ & 0.601 \\
\hline Communication & $17.3 \pm 3.8$ & 121 & $70.8 \%$ & 31 & $18.1 \%$ & 19 & $11.1 \%$ & 0.606 \\
\hline Overall & $135.3 \pm 24.8$ & 63 & $36.8 \%$ & 83 & $48.5 \%$ & 25 & $14.6 \%$ & 0.895 \\
\hline
\end{tabular}

Notes

1Overall satisfaction - Satisfied: $>=144$, Ambivalent: 109-143, Dissatisfied: $36-108$

${ }^{1}$ Sub-domain satisfaction - Satisfied: $>=16$, Ambivalent: 13-15, Dissatisfied: 4-12

${ }^{2}$ Reliability or internal construct validity is given as Cronbach's alpha coefficient 
Table 2 Sociodemographic characteristics of graduate nursing faculty

\begin{tabular}{|c|c|c|c|c|c|c|}
\hline \multirow[t]{2}{*}{ Characteristics } & \multicolumn{2}{|c|}{$\begin{array}{l}\text { Total } \\
(N=171)\end{array}$} & \multirow{2}{*}{$\begin{array}{l}\text { Not-Satisfied } \\
\text { (n0 }=108) \\
\% \text { or } \mu \pm \sigma\end{array}$} & \multirow{2}{*}{$\begin{array}{l}\text { Satisfied } \\
(\mathrm{n} 1=63) \\
\% \text { or } \mu \pm \sigma\end{array}$} & \multirow[t]{2}{*}{$\begin{array}{l}p- \\
\text { value }^{1}\end{array}$} & \multirow[t]{2}{*}{$\begin{array}{l}\text { Effect } \\
\text { Size }^{2}\end{array}$} \\
\hline & Count & $\%$ or $\mu \pm \sigma$ & & & & \\
\hline \multicolumn{7}{|l|}{ Age category } \\
\hline 35 or younger & 91 & $53.2 \%$ & $61.1 \%$ & $39.7 \%$ & \multirow[t]{3}{*}{0.011} & \multirow[t]{3}{*}{0.230} \\
\hline 36 to 45 years & 56 & $32.7 \%$ & $29.6 \%$ & $28.1 \%$ & & \\
\hline 46 and older & 24 & $14.0 \%$ & $9.3 \%$ & $22.2 \%$ & & \\
\hline \multicolumn{7}{|l|}{ Sex } \\
\hline Female & 166 & $97.1 \%$ & $99.1 \%$ & $93.7 \%$ & \multirow[t]{2}{*}{0.056} & \multirow[t]{2}{*}{0.155} \\
\hline Male & 5 & $2.9 \%$ & $0.9 \%$ & $6.4 \%$ & & \\
\hline \multicolumn{7}{|l|}{ Current Position } \\
\hline Lecturer or lower & 114 & $66.7 \%$ & $74.1 \%$ & $54.0 \%$ & \multirow[t]{3}{*}{0.027} & \multirow[t]{3}{*}{0.206} \\
\hline Assistant Professor & 25 & $14.6 \%$ & $11.1 \%$ & $20.6 \%$ & & \\
\hline Associate Professor + & 32 & $18.7 \%$ & $14.8 \%$ & $25.4 \%$ & & \\
\hline \multicolumn{7}{|l|}{ Highest Degree } \\
\hline Masters in Nursing & 95 & $55.6 \%$ & $56.5 \%$ & $54.0 \%$ & \multirow[t]{3}{*}{0.781} & \multirow[t]{3}{*}{0.054} \\
\hline MSc in Nursing & 70 & $40.9 \%$ & $40.7 \%$ & $41.3 \%$ & & \\
\hline PhD in Nursing & 6 & $3.5 \%$ & $2.8 \%$ & $4.8 \%$ & & \\
\hline \multicolumn{7}{|l|}{ Specialty in Nursing } \\
\hline Child Health & 30 & $17.5 \%$ & $16.7 \%$ & $19.1 \%$ & \multirow[t]{5}{*}{0.785} & \multirow[t]{5}{*}{0.101} \\
\hline Community Health & 12 & $7.0 \%$ & $7.4 \%$ & $6.4 \%$ & & \\
\hline Adult Health & 65 & $38.0 \%$ & $40.7 \%$ & $33.3 \%$ & & \\
\hline Mental Health & 18 & $10.5 \%$ & $11.1 \%$ & $9.5 \%$ & & \\
\hline Maternal Health & 46 & $26.9 \%$ & $24.1 \%$ & $31.8 \%$ & & \\
\hline \multicolumn{7}{|l|}{ Primary Responsibility } \\
\hline BSN Level & 146 & $85.4 \%$ & $90.7 \%$ & $76.2 \%$ & \multirow[t]{2}{*}{0.009} & \multirow[t]{2}{*}{0.199} \\
\hline MSN Level & 25 & $14.6 \%$ & $9.3 \%$ & $23.8 \%$ & & \\
\hline \multicolumn{7}{|l|}{ Tenure status } \\
\hline Temporary & 71 & $41.5 \%$ & $51.9 \%$ & $23.8 \%$ & \multirow[t]{2}{*}{0.000} & \multirow[t]{2}{*}{0.275} \\
\hline Permanent & 100 & $58.5 \%$ & $48.1 \%$ & $76.2 \%$ & & \\
\hline Teaching Experience (Years) & & & & & & \\
\hline After Master's degree & & $5.5 \pm 4.8$ & $4.7 \pm 3.9$ & $6.8 \pm 5.7$ & 0.014 & 0.209 \\
\hline At current institution & & $4.9 \pm 4.6$ & $3.7 \pm 3.0$ & $7.1 \pm 6.0$ & $<.0001$ & 0.362 \\
\hline At current position & & $3.2 \pm 3.1$ & $2.7 \pm 2.0$ & $3.9 \pm 4.4$ & 0.054 & 0.176 \\
\hline${ }^{3}$ Salary and Benefits $(' 00,000)$ & & & & & & \\
\hline Monthly Gross Salary (NRs) & & $5.5 \pm 1.5$ & $5.2 \pm 1.1$ & $6.1 \pm 2.0$ & 0.001 & 0.307 \\
\hline Monthly Basic Salary (NRs) & & $3.6 \pm 1.5$ & $3.3 \pm 1.0$ & $4.3 \pm 1.9$ & 0.000 & 0.327 \\
\hline Age (in years) & & $36.8 \pm 7.0$ & $35.7 \pm 6.2$ & $38.8 \pm 7.8$ & 0.008 & 0.217 \\
\hline
\end{tabular}

Notes

1 pvalue: $p$-values are based on chi-square test statistics for categorical variables and t-test statistics for continuous variables between satisfied and not-satisfied ${ }^{2}$ Effect size: the magnitude and direction of relationship with outcome are based on Cramer's V statistics for categorical variables and point biserial correlation (Pearson) for continuous variables

${ }^{3}$ Salary levels: basic salary is the fixed monthly salary whereas gross salary includes provident fund, grades, special allowances

Tables 2 and 3 above) were included in the initial model. Univariate logistic regression (not shown in these tables) also suggested the selection of these variables. All variables that were selected based on the high correlation with job satisfaction were further evaluated for possible collinearity and strong association among each other. Cramer's V test statistics were used to check for each pair of categorical variables. A cutoff point of 0.50 was 
Table 3 Organization related characteristic of nursing faculty

\begin{tabular}{|c|c|c|c|c|c|c|}
\hline \multirow[t]{3}{*}{ Characteristics } & \multicolumn{2}{|l|}{ Total } & \multirow{3}{*}{$\begin{array}{l}\text { Not-Satisfied } \\
\left(\mathrm{n}_{0}=108\right) \\
\%\end{array}$} & \multirow{3}{*}{$\begin{array}{l}\text { Satisfied } \\
\left(n_{1}=63\right) \\
\%\end{array}$} & \multirow{3}{*}{$\begin{array}{l}\text { p- } \\
\text { value }^{1}\end{array}$} & \multirow{3}{*}{$\begin{array}{l}\text { Effect } \\
\text { Size }^{2}\end{array}$} \\
\hline & \multicolumn{2}{|c|}{$(N=171)$} & & & & \\
\hline & Count & $\%$ & & & & \\
\hline \multicolumn{7}{|l|}{ Type of Institution } \\
\hline Private & 104 & $60.8 \%$ & $67.6 \%$ & $49.2 \%$ & \multirow[t]{2}{*}{0.018} & \multirow[t]{2}{*}{0.182} \\
\hline Public & 67 & $39.2 \%$ & $32.4 \%$ & $50.8 \%$ & & \\
\hline Promotional opportunity & 97 & $56.7 \%$ & $47.2 \%$ & $73.0 \%$ & 0.001 & 0.251 \\
\hline Grade opportunity & 131 & $76.6 \%$ & $69.4 \%$ & $88.9 \%$ & 0.004 & 0.222 \\
\hline Provident fund benefits & 109 & $63.7 \%$ & $50.0 \%$ & $87.3 \%$ & $<.0001$ & 0.374 \\
\hline Healthcare benefits & 127 & $74.3 \%$ & $66.7 \%$ & $87.3 \%$ & 0.003 & 0.228 \\
\hline \multicolumn{7}{|l|}{ Involved in decision making } \\
\hline Never or Rarely & 55 & $32.2 \%$ & $40.7 \%$ & $17.5 \%$ & \multirow[t]{3}{*}{0.002} & \multirow[t]{3}{*}{0.274} \\
\hline Sometimes & 59 & $34.5 \%$ & $34.3 \%$ & $34.9 \%$ & & \\
\hline Often or Always & 57 & $33.3 \%$ & $25.0 \%$ & $47.6 \%$ & & \\
\hline Provision of supervisory Pay & 56 & $32.7 \%$ & $33.3 \%$ & $31.8 \%$ & 0.831 & -0.016 \\
\hline Provision of clinical Pay & 31 & $18.1 \%$ & $14.8 \%$ & $23.8 \%$ & 0.141 & 0.113 \\
\hline PM clinical & 147 & $86.0 \%$ & $91.7 \%$ & $76.2 \%$ & 0.005 & -0.215 \\
\hline AM clinical starting $\geq 8 \mathrm{am}$ & 79 & $46.2 \%$ & $41.7 \%$ & $54.0 \%$ & 0.120 & 0.119 \\
\hline Clinical duty $\geq 7 \mathrm{~h}$ & 77 & $45.0 \%$ & $39.8 \%$ & $54.0 \%$ & 0.073 & 0.137 \\
\hline \multicolumn{7}{|l|}{ Overall workload } \\
\hline Normal ( $\leq 41 \mathrm{~h})$ & 94 & $55.0 \%$ & $59.3 \%$ & $47.6 \%$ & \multirow[t]{2}{*}{0.140} & \multirow[t]{2}{*}{0.113} \\
\hline Overload ( $\geq 42 \mathrm{~h}$ ) & 77 & $45.0 \%$ & $40.7 \%$ & $52.4 \%$ & & \\
\hline \multicolumn{7}{|l|}{ Teaching load per year } \\
\hline$\leq 124 \mathrm{~h}$ & 75 & $43.9 \%$ & $38.0 \%$ & $54.0 \%$ & \multirow[t]{2}{*}{0.042} & \multirow[t]{2}{*}{-0.156} \\
\hline$\geq 125 \mathrm{~h}$ & 96 & $56.1 \%$ & $62.0 \%$ & $46.0 \%$ & & \\
\hline \multicolumn{7}{|l|}{ Professional Development } \\
\hline$\leq 4$ days & 95 & $55.6 \%$ & $65.7 \%$ & $38.1 \%$ & \multirow[t]{2}{*}{0.000} & \multirow[t]{2}{*}{0.268} \\
\hline$\geq 5$ days & 76 & $44.4 \%$ & $34.3 \%$ & $61.9 \%$ & & \\
\hline Adequate textbook & 128 & $74.9 \%$ & $66.7 \%$ & $88.9 \%$ & 0.001 & 0.247 \\
\hline Adequate reference book & 113 & $66.1 \%$ & $55.6 \%$ & $84.1 \%$ & 0.000 & 0.291 \\
\hline Adequate Med/Nursing Journals & 98 & $57.3 \%$ & $45.4 \%$ & $77.8 \%$ & $<.0001$ & 0.316 \\
\hline Adequate internet facilities & 143 & $83.6 \%$ & $77.8 \%$ & $93.7 \%$ & 0.007 & 0.207 \\
\hline Question setting for tests & 85 & $49.7 \%$ & $41.7 \%$ & $63.5 \%$ & 0.006 & 0.211 \\
\hline \multicolumn{7}{|l|}{ Benefits offered ( $\mu=$ Rs56K) } \\
\hline Below average & 118 & $69.0 \%$ & $75.9 \%$ & $57.1 \%$ & \multirow[t]{2}{*}{0.010} & \multirow[t]{2}{*}{0.196} \\
\hline Above average & 53 & $31.0 \%$ & $24.1 \%$ & $42.9 \%$ & & \\
\hline
\end{tabular}

Notes

${ }^{1} p$-value: all p-values are based on Chi-square test statistics

${ }^{2}$ Effect size: the magnitude and direction of relationship of all categorical variables with the outcome are based on Cramer's V test statistics

established for unusually high correlation at which point two variables were probably measuring the same concept.

Being tenured had a strong correlation with provident fund (0.70) and grade (0.54). In Nepalese context, whether it is a public or private institution, a permanent employment (tenured status) usually requires the employer to provide both provident fund and grade (0.59) but employers can extend these benefits to nonpermanent employees at any time. Since majority of the faculty worked in private sector colleges, an employer matched provident fund may have greater value towards their saving for the future. Therefore, only provident fund benefit was chosen to enter the model. Similarly, strong association was detected between current position and level of primary teaching responsibility (0.57) and 
total compensation above median (0.52). However, effect size between master's program and total compensation was much lower (0.37) and both primary responsible program and total compensation were entered in the model without current position. Adequate textbook and reference book were also strongly related (0.64) and only adequate reference book which had higher correlation with outcome was selected (Fig. 2).

Table 4 shows the results from multiple logistic regression model where the job satisfaction is the function of many variables. The area under curve of the receiver operating curve showed very strong discriminatory power (AUC $=0.855$ ) of the model. This means that the logistic regression model can accurately classify the predicted outcome as satisfied or not-satisfied for every possible pair of observations for $85.5 \%$ of the pairs. The likelihood ratio test $(p<0.0001)$ and Hosmer and Lemeshow goodness of fit statistics $(p=0.609)$ also indicate that the model is well behaved. However, a majority of the individual variables included in the model do not have a statistically significant coefficient and have a very wide odds ratio interval.

Table 4 showed that faculties involvement in decision making (higher job satisfaction with higher involvement levels) and adequate reference books came out to be the only strongly significant variables $(p<0.05)$ in the model. Faculties who were involved in departmental decisionmaking processes 'sometimes' and 'often or always' were 3.6 and 4.83 times more likely to be satisfied respectively than those who were never or rarely involved. It is interesting to note that the lowest job satisfaction (Table 1) was in the domain "operating conditions". It suggests

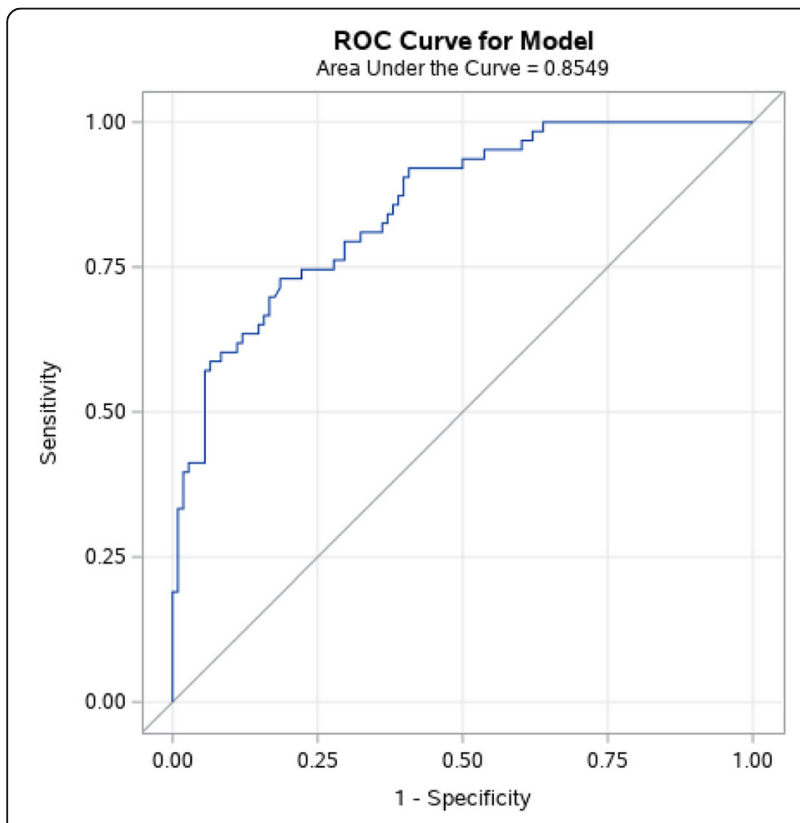

Fig. 2 Area Under the Curve for the Multiple Logistic Regression Model that job satisfaction is high when faculties are included in the decision-making process and they feel part of the 'system'. Similarly, their job satisfaction is higher ( $\mathrm{OR}=$ 2.92, $p=0.050$ ) when reference books were adequately available for themselves and the student.

Although the adjusted odds ratios were not significant at $5 \%$ level of significance and $95 \%$ confidence interval, there were positive indicators of job satisfaction with various factors identified during the descriptive analysis. The nursing faculties were more likely to be satisfied with availability of medical or nursing journals $(\mathrm{OR}=2.32, p=0.090)$ and internet access $(\mathrm{OR}=3.92, p=0.100)$. They were $64 \%$ more likely to be satisfied ( $\mathrm{OR}=1.64, p=0.378)$ when they were involved in setting questions for the final exams, which is often regarded a greater respect to the faculty in Nepal. They were more likely to be satisfied with their job when they did not have evening clinical ( $\mathrm{OR}=3.30, p=0.069)$, could start their AM clinical at 8 am or later instead of earlier in the morning $(\mathrm{OR}=1.54, p=0.352)$, had a weekly work load of less than $42 \mathrm{~h}(\mathrm{OR}=1.98, p=0.198)$, had an annual teaching load less than $125 \mathrm{~h}(\mathrm{OR}=2.41, p=0.082)$, and were provided with more than 5 days of professional development opportunities $(\mathrm{OR}=2.34, p=0.072)$.

\section{Discussion}

This study was conducted to explore the factors associated with job satisfaction among the nursing faculties teaching at the baccalaureate level and above in different nursing colleges under seven Universities of Nepal. The findings would help identify factors that may be modified to improve job satisfaction among these faculties, leading to higher retention of faculties and improving the overall quality of nursing education.

There have been few small-scale job satisfaction studies in Nepal with varying results prior to this study. The findings of this study support the findings of a study conducted in the Chitwan district of Nepal which shows majority of the faculties had ambivalent feeling towards their job [8]. The finding of this study also support a study conducted in the Kathmandu valley of Nepal which showed just one-third of faculty were satisfied with their job [9]. This study found that organizational commitment was an important factor in maintaining job satisfaction among nursing faculties [9].

Compared to several studies conducted in the United States of America and Australia where job satisfaction among nursing faculties was reported between 18 and $45 \%[10,12-14]$, the $36.8 \%$ job satisfaction rate of this study seems reasonable.

Moody et al. found a significant positive relationship between years at the current institution and satisfaction with pay, coworkers, and the job in general [10]. In current study, faculties seemed to be least satisfied with their current opportunities for promotion, contingency 
Table 4 Results of Multiple Logistic Regression Model

\begin{tabular}{|c|c|c|c|c|c|}
\hline \multirow{2}{*}{$\begin{array}{l}\text { Parameter } \\
\text { Intercept }\end{array}$} & \multirow{2}{*}{$\begin{array}{l}\text { Estimate } \\
-7.437\end{array}$} & \multirow{2}{*}{$\begin{array}{l}\text { Pr }>\text { ChiSq } \\
0.000\end{array}$} & \multirow{2}{*}{$\begin{array}{l}\text { Odds Ratio } \\
\text { Point }\end{array}$} & \multicolumn{2}{|c|}{ 95\% Cl Odds Ratio } \\
\hline & & & & $\mathrm{LL}$ & UL \\
\hline \multicolumn{6}{|l|}{ Age Group (ref: <=35 years) } \\
\hline Age $36-45$ years & -0.067 & 0.900 & 0.935 & 0.325 & 2.645 \\
\hline Age 46 and older & 0.539 & 0.485 & 1.714 & 0.368 & 7.864 \\
\hline Male Gender & 0.255 & 0.858 & 1.290 & 0.097 & 37.071 \\
\hline \multicolumn{6}{|l|}{ Specialty (ref: Adult Health) } \\
\hline Child Health & 0.563 & 0.347 & 1.756 & 0.543 & 5.785 \\
\hline Community Health & -0.327 & 0.746 & 0.721 & 0.094 & 5.254 \\
\hline Mental Health & 0.533 & 0.517 & 1.704 & 0.330 & 8.571 \\
\hline Maternal Health & 0.685 & 0.209 & 1.984 & 0.685 & 5.895 \\
\hline Responsibility in MSN & -0.115 & 0.885 & 0.892 & 0.181 & 4.165 \\
\hline Public Institution & 0.085 & 0.866 & 1.088 & 0.403 & 2.910 \\
\hline Provident Fund Benefits & 0.842 & 0.155 & 2.320 & 0.737 & 7.685 \\
\hline Healthcare Benefits & 0.299 & 0.618 & 1.348 & 0.416 & 4.491 \\
\hline \multicolumn{6}{|l|}{ Decision Making (ref: Never or Rarely) } \\
\hline Sometimes & 1.282 & 0.044 & 3.602 & 1.073 & 13.335 \\
\hline Often or Always & 1.575 & 0.019 & 4.833 & 1.353 & 19.111 \\
\hline No clinical in PM & 1.194 & 0.069 & 3.299 & 0.924 & 12.357 \\
\hline AM Clinical after 7 AM & 0.435 & 0.352 & 1.544 & 0.617 & 3.894 \\
\hline Weekly Work Overload (ref: < 42 h/wk) & 0.683 & 0.198 & 1.979 & 0.720 & 5.844 \\
\hline Lower Course Load (ref: > = 125 h/yr) & 0.881 & 0.082 & 2.414 & 0.907 & 6.726 \\
\hline Professional Development (ref: $<5$ days) & 0.852 & 0.072 & 2.343 & 0.933 & 6.053 \\
\hline Adequate Reference Books & 1.072 & 0.050 & 2.922 & 1.026 & 8.953 \\
\hline Adequate Medical/Nursing Journals & 0.842 & 0.090 & 2.321 & 0.888 & 6.299 \\
\hline Adequate Internet Access & 1.367 & 0.100 & 3.922 & 0.856 & 23.701 \\
\hline Privilege to Set Questions for Test & 0.495 & 0.378 & 1.641 & 0.541 & 4.966 \\
\hline Total compensation above median & 0.093 & 0.852 & 1.098 & 0.408 & 2.940 \\
\hline Long Institutional Tenure (ref: < 7yrs) & 0.427 & 0.442 & 1.533 & 0.516 & 4.628 \\
\hline \multicolumn{6}{|l|}{ Model Performance Measures: } \\
\hline Max-rescaled R-Square & & 0.469 & & & \\
\hline Likelihood Ratio Test (p-value) & & $<.0001$ & & & \\
\hline Area Under Receiver Operating Curve & & 0.855 & & & \\
\hline Hosmer-Lameshow Goodness-of-Fit ( $p$-value) & & 0.609 & & & \\
\hline
\end{tabular}

Health Care benefits: Employee welfare benefit provided by an employer that provide medical care for the employee and their dependents (Father and mother or father-in-law and mother-in-law, husband/wife, children)

rewards, operating conditions, payment and fringe benefits. Nursing faculties seemed to be dissatisfied with their professional promotion in this study, which is consistent with studies done in Canada [15] and the USA [16]. Promotion of nursing faculties often tied with their participation in research activities. Fourty five percentage of the nursing faculties were already working $42 \mathrm{~h}$ or more per week (Table 1). A promotion criterion based on number of research publications in peer reviewed journals often created additional burden on faculty. Barret et al. had found that the nursing faculties were least satisfied with an extrinsic factor like their participation in research related activities [16].

As seen in the domain wise job satisfaction scores, faculties were least satisfied with the existing operating conditions that involved excessive workloads, lots of paperwork, non-participatory decision making, and many rules and regulations that make their job more difficult. These findings are in congruence to the study by Barrett et al. which showed that the faculties were least satisfied with the excessive workload [15]. In a study conducted in the United Kingdom, McHale found that 
the nursing teachers were dissatisfied with excessive paperwork and suggested a reexamination of teacher's workload to alleviate both quantitative and qualitative overload [17]. Shortage of nursing faculties, often resulting in higher student-faculty ratio, and vague job descriptions could contribute to the burden nursing faculty feel at work.

Low satisfaction regarding payment/salaries in this study was similar to the results of a study by Thies et al. [18]. The nursing faculties in this current study were satisfied with their coworkers, nature of work, communication and supervision, which supports reports from several other studies [10, 16-19].

Multiple regression analysis showed that an easy access to adequate reference books, internet, and clinical/ nursing journals in their workplace were some of the key factors in the faculties' job satisfaction. The availability of adequate references books are a cornerstone in the improvement of the knowledge and skills of both the nurses working in hospitals $[20,21]$ and nursing faculties working in colleges.

The faculties' involvement in decision making process was another significant key factor of job satisfaction. A prior study conducted in the United States also showed faculties participation in decision making, an autonomy or intrinsic factor, as the key factor for job satisfaction [16].

Although we selected variables based on their high correlation with the outcome from the univariate analysis, most variables were not statistically significant in the multiple regression model. This suggests that job satisfaction outcome is the result of many interrelated variables. While individual variables were strongly related with the outcome during univariate analysis, their effect was neutralized in the presence of other variables. Collectively, the set of variables used in the model was able to discriminate job satisfaction outcome with very high degree of accuracy. The researchers suggest that the association between individual variable and outcome be taken as indicative rather than deterministic of overall job satisfaction.

\section{Limitations}

One of the limitations of this study was that only highly motivated faculties were willing to participate in the study which may have introduced some outcome bias. Moreover, few of the participants did not have easy access to internet and did not respond to emails frequently, which limited the timely delivery of the response. Due to the lack of national registry system with the contact details of the nursing faculties working in different organization in the country, it was difficult to retrieve the contact details of the participants and some of the surveys were returned as undeliverable.

\section{Conclusion}

Findings from this study shows only a few faculties were satisfied with their opportunities and criteria used for promotion, contingency rewards, operating conditions, payment and fringe benefits. The operating conditions included many rules and procedures resulting in lower work efficiency, and new ideas that encourage faculty innovation were not adequately promoted. Although payment was one of the lowest ranked job satisfaction domains, many non-monetary factors played key role in overall job satisfaction. While many variables had individually strong correlation with job satisfaction, the contribution from each of those variables were smaller when controlling for each other in a multivariate analysis. The researchers suggest that the association between individual variable and overall job satisfaction be taken as indicative than deterministic.

\section{Abbreviations}

BPKIHS: BP Koirala Institute of Health Sciences; KU: Kathmandu University; MN: Masters' in Nursing; MSc Nursing: Masters' in Science in Nursing; NAMS: National Academy of Medical Sciences; NHRC: Nepal Health Research Council; NMC: Nepal Medical College; PAHS: Patan Academy of Health Sciences; PD: Professional Development; PhD: Doctorate in philosophy; PokhU: Pokhara University; PU: Purbanchal University; SPSS: Statistical Package for the Social Sciences; TU: Tribhuvan University

\section{Acknowledgements}

We would like to thank the authorities of different colleges for granting permission to conduct the study, coordinators and the nursing faculties for their active participation in the study. Our sincere thanks to Mr. Paul Spector, the developer of job satisfaction survey tool for his kind permission to use the tool with some modification. We also like to thank Daniel Sapkota for guiding us in the transformation of questionnaire on online form.

\section{Authors' contributions}

AS- conceptualized the study, coordinated with the authorities of different nursing colleges, collected data, entered the data and analyzed them, and also developed the final manuscript. UKP-Collected data and analyzed the data. AS- Conceptualized the study, reviewed the literature and prepared the manuscript. GRB- statistical analysis, prepared and thoroughly reviewed the final manuscript. JP, PG, BT \& TKC-Conceptualized the study, collected data and frequently coordinated with the faculties. All authors read and approved the final manuscript.

\section{Funding}

This study was conducted with a research grant from Nepal Medical College, Jorpati, Kathmandu, Nepal. There was no active role of the funding organization in the study, however, the fund was used in the collection and interpretation of data.

\section{Availability of data and materials}

Data will not be shared to ensure patient confidentiality.

\section{Ethics approval and consent to participate}

Written permission was taken from the author of job satisfaction survey (JSS). Written administrative approval from organizational authorities of each college and ethical approval from Institutional Review committee of Nepal Medical college (NMC-IRC) and NHRC was obtained (Approval date: 25 June, 2017- Ref no- 34-072/073; Approval date: 13 August, 2017-Reg. no.249/2017). Written informed consent was taken from the respondents and their rights were protected by maintaining confidentiality and privacy. Anonymity was assured by requesting respondents not to write their names or any identifiable marks on the questionnaires. 


\section{Consent for publication}

Not applicable as no individual detail is presented in this report.

\section{Competing interests}

The authors declare that they have no competing interests.

\section{Author details}

'Department of Nursing, Nepal Medical College, Gokarneshwor- 44602, Attarkhel, Jorpati Kathmandu, Nepal. ${ }^{2}$ Pokhara Nursing Campus, Pokhara, Nepal. ${ }^{3}$ Nepal Medical College, Attarkhel, Jorpati, Kathmandu, Nepal. ${ }^{4}$ Chitwan Medical College, Bharatpur, Chitwan, Nepal. ${ }^{5}$ Optumlnsight, Minneapolis, MN, USA. 'Kathmandu University School of Medical Sciences, Dhulikhel, Kavre, Nepal. ${ }^{7}$ Maharajgunj Nursing Campus, Maharjgunj, Kathmandu, Nepal.

Received: 12 June 2019 Accepted: 24 October 2019

Published online: 28 November 2019

\section{References}

1. Hayne AN, Gerhardt C, Davis J. Filipino nurses in the United States recruitment, retention, occupational stress, and job satisfaction. J Transcult Nurs. 2009;20(3):313-22. https://doi.org/10.1177/1043659609334927.

2. McKenna E. Business psychology and organizational behavior: A Student's handbook. third ed. Philadelphia: Psychology Press; 2000

3. Bakotić D. Relationship between job satisfaction and organizational performance. Economic Research-Ekonomska Istraživanja. 2016;29(1):118-30. https://doi.org/10.1080/1331677X.2016.1163946.

4. Al-Hussami M, Saleh MYN, Abdalkader RH, Mahadeen Al. Predictors of nursing faculty members' organizational commitment in governmental universities. J of Nurs Manag. 2011;19:556-66. https://doi.org/10.1111/j.1365-2834.

5. Miao RT. Perceived organizational support, job satisfaction, task performance and organizational citizenship behavior in China. Ins of behav and applied manag. 2011;1:105-27.

6. Spector PE. Job satisfaction: application. Assessment: Causes and Consequences. SAGE Publications, London; 1997.

7. Kenny P, Reeve R, Hall J. Satisfaction with nursing education, job satisfaction, and work intentions of new graduate nurses. Nurse Educ Today 2016:36:230-5. https://doi.org/10.1016/j.nedt.15.10.023.

8. Baral R, Bhatta R. Job Satisfaction among Nursing Faculties of Chitwan District. J College Med Sci Nepal. 2018;14(4):221-4. https://doi.org/10.3126/ jcmsn.v14i4.22559.

9. Timalsina R, KC S, Rai N, Chhantyal A. Predictors of organizational commitment among university nursing Faculty of Kathmandu Valley, Nepal. BMC Nursing. 2018;17:30. https://doi.org/10.1186/s12912-018-0298-7.

10. Moody NB. Nurse faculty job satisfaction: a national survey. J Prof Nurs. 1996;12(5):277-88

11. Spector P.E. Job Satisfaction Survey, JSS Page Retrieved on 4/21/2017 from http://shell.cas.usf.edu/ pspector/scales/jsspag.html.

12. Jackson, Annette J. Nurse Faculty Job Satisfaction: Development and Evaluation of the Nurse Educator Satisfaction Index. Doctorate of Nursing Science Dissertations. Wellstar School of Nursing, Kennessaw State University, GA, USA. 2016. [Cited 2019 July 5]. Available from: https:// digitalcommons.kennesaw.edu/cgi/viewcontent.cgi?article=1003\&context= dns_etd.

13. Westphal J, Marnocha S, Chapin T. A pilot study to explore nurse educator workforce issues. Nurs Educ Perspect. 2016;37(3):171-3. https://doi.org/10. 5480/14-1332.

14. Sayers JM, Salamonson Y, DiGiacomo M, Davidson P. Nurse educators in Australia: high job satisfaction despite role ambiguity. J Nursing Educ Practice. 2015;5(4):41-51. https://doi.org/10.5430/jnep.v5n4p41.

15. Barrett MC, Goldenberg D, Faux S. Career patterns and job satisfaction of Canadian nurse educators. J Adv Nursing. 1992;17:1002-'. https://doi.org/10. 1111/j.1365-2648.1992.tb02030.x.

16. Snarr CE, Krochalk PC. Job satisfaction and organizational characteristics: results of a nationwide survey of baccalaureate nursing faculty in the United States. J Adv Nurs. 1996;24:405-12. https://doi.org/10.1046/j.13652648.1996.19725.x.

17. McHale C. Job mobility among nurse teachers. Nurs Stand. 1991:6(1):30-2. https://doi.org/10.7748/ns.6.1.30.s47.
18. Thies KM, Serratt T. Evaluating association degree nursing faculty job satisfaction. Teaching Learning Nursing. 2018;13:71-4. https://doi.org/10. 1016/j.teln.2017.12.008

19. Disch, J, Edwardson,S, Adwan, J. Nursing faculties satisfaction with individual, institutional factors, leadership factors. J Prof Nurs 2004;20:323331. DOI: https://doi.org/10.1016/j.profnurs.2004.07.011.

20. Grandjean BD, Aiken LH, Bonjean CM. Professional autonomy and the work satisfaction of nursing educators. Nursing Res. 1976;25(3):216-21. https://doi. org/10.1097/00006199-197605000-00018.

21. Laschinger HK. Job and career satisfaction and turnover intentions of newly graduated nurses. J Nurs Manag. 2012;20(4):472-84. https://doi.org/10.1111/ j.1365-2834.2011.01293.x

\section{Publisher's Note}

Springer Nature remains neutral with regard to jurisdictional claims in published maps and institutional affiliations.
Ready to submit your research? Choose BMC and benefit from:

- fast, convenient online submission

- thorough peer review by experienced researchers in your field

- rapid publication on acceptance

- support for research data, including large and complex data types

- gold Open Access which fosters wider collaboration and increased citations

- maximum visibility for your research: over $100 \mathrm{M}$ website views per year

At BMC, research is always in progress.

Learn more biomedcentral.com/submissions 